\title{
Levels of life: Modernity and modernism in David Malouf's Fly Away Peter
}

Kay Ferres

k.ferres@griffith.edu.au

\section{Abstract}

David Malouf's novel Fly Away Peter (1982) uses modernist techniques to describe the impact of modernity on the emergent Australian nation. At its centre is the country lad Jim Saddler, who dies in the industrialised battlefield in France. His fate is entwined with that of his friend Ashley Crowther, who inherits his family's property, and whose embrace of modernity includes a determination to preserve the land and its wildlife. Ashley recognises the value of Jim's instinctive connection with the natural world, and his knowledge of, and fascination with, birds. This fascination aligns Jim with the photographer Imogen Harcourt. Miss Harcourt is a modern woman, using the new technologies of representation to record the natural world, its movement and change. At the novella's end, it is Imogen who turns her lens towards a new future, as her grief for Jim is transfigured through an epiphanic vision of a surfer riding the waves to the beach.

David Malouf's 1982 novella Fly Away Peter has been reimagined as an opera as part of the international commemoration of the centenary of the Great War (1914-18). Premiered at Sydney's Carriageworks on 5 May 2015, Elliott Gyger's adaptation marries Malouf's story with Igor Stravinsky's Faustian work L'Histoire $d u$ Soldat, first performed in 1918. Malouf's regard for Stravinsky's work is evident in his 'Ode: Stravinsky's Grave', where he calls him 'the century's composer' (Malouf 1980). A theatrical work, L'Histoire $d u$ Soldat features seven musicians, three actors and a narrator, and a dancer. Gyger's score and Pierce Wilco's libretto reproduce elements of Stravinsky's instrumentation and staging, but the narrative, tone and mood of Malouf's work are preserved.

The continuities and contrasts with L'Histoire $d u$ Soldat highlight the modernism of Fly Away Peter. Both works respond to the horror of war, but Stravinsky's homecoming soldier loses his soul, while Malouf's merely loses his life. Like Stravinsky, Malouf pares back an epic story to its essential elements. Stravinsky's avant-garde work scores a septet of clarinet, bassoon, cornet, trombone, percussion, violin and double bass in a variety of styles, including folk music, waltz, tango and ragtime. The musicians all play as soloists (Denti 2013: 20) and are on stage with the 
actors (the Devil, the Soldier and the Princess), the narrator and a female dancer (2013: 44). Malouf's novella references romantic and modern music, played on piano and gramophone, and describes an improvised concert performed behind the lines in France. Gyger's adaptation recognises these correspondences. Gyger uses three voices, to represent Jim Saddler, Ashley Crowther and Imogen Harcourt, and a chorus. Stravinsky's devil is silenced, although I would suggest he does have a counterpart in Fly Away Peter, in the figure of Wizzer Green, who threatens to bring out Jim's worst self, and with whom he struggles almost to the death in the midst of no man's land. Gyger's score introduces an instrumental line to represent the birds that are so integral to Jim's view of the world, and that figure as symbols of his best self.

Gyger (2015: 3) describes how his score creates aural landscapes that represent Australia and France:

The framework of Fly Away Peter is a landscape-like organisation of pitch. 21 five-note chords, covering the full range of the ensemble, are laid out in an inversionally symmetrical grid. The chords are sometimes used in harmonies, but more often linearly: melodic motion may occur within chords, or between pitches from adjacent chords in the grid ... The inversional symmetry reflects the dichotomy between earth (the domain of man) and air (the domain of the birds) ubiquitous in the libretto.

While the framework provides room for contrast, the movement from peace to war demanded a more drastic reshaping: at the start of Scene 4 the musical landscape is virtually turned inside-out, as the same 21 chords are recast in a completely different arrangement and stacked on top of one another to build denser harmonies.

A violin line represents bird song, and a mezzo figures as a 'disembodied choric voice'. This reproduces critical elements of Malouf's vision: the birds whose migrations mark the seasonal cycle and offer the promise of regeneration, and whose appearance evokes surprise and joy; and Miss Harcourt's steady presence that culminates in her lament.

Malouf originally conceived Fly Away Peter as a long short story about birds. In Tuscany during the harsh winter of 1981, he read an account in the Times Literary Supplement of a bird sanctuary that had been established in East Anglia in 1914. He was reminded of the Currumbin Bird Sanctuary (established in 1947), a significant site of the emotional geography of his Queensland childhood. The first version of his story was about the sanctuary, and ended with the outbreak of war. It described the Gold Coast and its rich hinterland, encompassing surf beaches, swampland and scrub where the young working man, Jim Saddler, inhabited the natural world on the level of the birds that were his obsession. The themes of the 'bird story' reflected Malouf's interest in 'the question of how land is possessed, either legally or through imagination and spiritual identity' (Malouf 2015) that was to be given fuller expression in Harland's Half Acre (1984).

In the 'bird story', this theme is carried by Jim's relationship with the landowner Ashley Crowther, recently returned from Europe, who establishes a sanctuary and employs Jim to manage it. The final version of the novella extends the bird story, moving to the battlefields in France where Jim and the other young Queensland men who enlisted with him are plunged into the horror of the trenches. Pastoral idyll 
gives way to nightmare, to the phantasmagorical scenes of Jim's confrontation with his antagonist Wizzer Green, and his reunion with Ashley prior to his death. This structural shift, from the natural world to the interior spaces of the mind, recalls Joseph Conrad's novella Heart of Darkness (1899), also originally conceived as a shorter story with a single focus. As in Conrad's case, the expansion of the original vision to include the journey to the geographic and psychological interior has shaped critical reception of the work. It is Conrad's compelling account of 'the horror' that confronts Marlow and challenges his understanding of human nature that is most remembered, and as Malouf (2015) acknowledges, Fly Away Peter 'is commonly thought of as a First World War book' depicting the horrors of battle. The novella's coda, focused on Imogen Harcourt, deals with the war's 'most powerful legacy': the loss of a generation of young men (Malouf 2015).

In 2003, Malouf analysed shifting national sentiment surrounding Australia's involvement in foreign wars in an essay titled 'The One Day'. The title invokes Alan Seymour's influential play, The One Day of the Year (1958), to argue that Anzac Day has become a truly national occasion, making space for 'shared attitudes and affections and loyalties and concerns' (Malouf 2003: 95) where once it had been a site of public contention. In the period of the Cold War, 'what the day represents and who has the right to define and manage it' had been subject to 'long and sometimes bitter argument' (2003: 95). This bitterness is vividly realised in Seymour's play. But the passing of time and the inevitable loss of living memory of the war allowed a new sentiment to take hold.

In the essay, Malouf examines the role writers have played in shaping the Anzac tradition:

One of the uses of art is that it allows us to re-experience what has most deeply wounded us, at an imaginative level where it might also be healing. We needed a literature of the First World War, and, in fact, we now have one, but it was written out of the imagination by a later generation ... The men who had actually been there remained silent to the end. (2003: 99)

Malouf sees the 'old habit of silence about what was most deeply felt' as characteristic of an older generation of Australians and of Australian writing. It created the strengths and limitations of writing that concerned itself with 'masculine action in a world of men, excluding virtually everything introspective or inward' (2003: 98). It might be said of Malouf that his work has penetrated the introspective and the inward, mapping a space where individual action and conscience play out in the margins of public life. This is the subject of Fly Away Peter.

Modernism's engagement with the introspective and the inward - through stream of consciousness and shifting focalisation - and its emphasis on perception over interpretation of experience shape the narration in Fly Away Peter. It also shares in modernist writers' interest in social change and the shock of the new. Iconic imagery of modernity figures in the novella from the start: the biplane piloted by Ashley's friend Bert appears in the opening and closing scenes of Part 1 (Chapters 1 and 8). Its first appearance disturbs Jim, as he lies full-length on the earth - his typical posture is horizontal, on a level with the birds whose nesting he observes and records. The plane is heavy and clumsy; it cannot reproduce the graceful, light manner of the swooping birds: 'It was a new presence here and it made Jim Saddler uneasy ... the lack of pattern in its lumbering passes and the 
noise it made, which was also a disturbance and new' (Malouf 1982: 2). When Jim is finally persuaded to don goggles and skullcap to go on a 'joy flight', fear seizes him. But his bird's eye view confirms that the map he carries in his head is 'a true picture' of the terrain he knows so well, and he speculates that this map might be 'related to the ones the birds carried in theirs, which allowed them to find their way ... halfway across the world' (1982: 54). Jim is in awe of the birds: their unerring sense of direction, their command of the air and their delicate movements on land. But he is a terrestrial creature, more at home on the warm earth. He has none of the daring of Bert or Ashley. The marvel of heavier than air flight holds no wonders for him.

This technology was refined in modernity to be militarily deployed in the Great War. Even as Jim climbs into the plane,

These machines ... had entered a new dimension. After just a few seasons of gliding over the hills and occasionally clipping the tops of trees, new toys of a boyish but innocent adventuring, they had changed their nature and become weapons. Already they were being used to drop bombs and had been organised, in Europe, into a new fighting arm. (1982: 51)

Bert is part of this transformation. Within weeks he sets sail for Europe, exchanging joy rides in the crate that he assures Jim is 'safe as houses' for deadly forays into enemy territory.

A second technology of modernity — photography — is central to establishing the novella's ethos. Photography is the technology of epiphany, the visual equivalent of the trope most closely associated with literary modernism. This new, portable technology also brings the modern woman into this otherwise masculine narrative of young men in a new world. Imogen Harcourt frames the narrative of a lost generation of men, just as she frames the image of the sandpiper. Even through the tears that she sheds for Jim, she clearly sees what his sacrifice means.

The novella's narrative structure and its lyricism have much in common with the new aesthetic of photography, as described by Roland Barthes in Camera Lucida (1980). This now classic study was published in English in 1982, but the original French text, La chambre clair, was reviewed in the Times Literary Supplement in November 1980 (Batchen 2009: 15), so Barthes' ideas were already known to readers of the Times Literary Supplement, such as Malouf. Barthes identified two dimensions of the photograph, providing a critical vocabulary that is still in use: the studium, or manifest content; and the punctum, the arresting detail — the moment that disrupts ordinary vision, introduces the idea of death and releases feelings of loss and grief (Barthes 1982). Writing in The Guardian about Barthes' continuing influence, Brian Dillon (2011: 1) describes the book not as a 'semiotics' but as a 'ghost story'; less an academic analysis of photography than a 'story of love and grief'. Dillon reminds us of the 'scandalous ... embrace of the subjective' enacted in Barthes' confession that he cried when he first saw the picture of his mother as a girl, and suggests that it is this 'astonishing' narrative moment that explains why the study is so moving (2011:2). Barthes' ideas can be applied to the visual landscapes of Fly Away Peter, to its embrace of subjective experience and to its final image of Imogen's tears. The studium describes Australia's rural social democracy and the impact of the nation's being catapulted into war, and the punctum articulates the pointlessness of war through piercing moments centred on key events of Jim's life 
and death. The photographer Imogen Harcourt, a double for the author, lays Jim's ghost to rest.

Jim's fascination with birds is shared with Imogen, whom he meets unexpectedly at the swamp. He later turns up at her cottage unannounced, eager to see her photographs. He realises that her images offer another level of understanding of the natural phenomena they mechanically reproduce. While he carefully records details of his observations of the birds' migrations and habitats, and readily identifies their calls, Imogen's photographs give them vivid, almost mystical life. Her images seem to expose their souls:

It was the sandpiper. Perfect. Every speckle, every stripe on the side where it faded off into the white of the underbelly, the keen eye in the lifted head - he felt oddly moved to see the bird in another dimension ... Did she know so much about birds? Or did some intuition guide her? This is it; this is the moment when we see into the creature's unique life. That too might be a gift. (Malouf 1982: 26-7, emphasis in original)

A solitary figure like Jim, Imogen has the gift of seeing into his unique life and will feel his loss, as he misses her when he finds himself in another hemisphere. Camped with the other recruits on Salisbury Plain, Jim thinks of Imogen when he sees the birds that were so familiar to her. Back at the swamp, the two friends had been astonished to see a dunlin, a bird that does not occur in Queensland, a refugee from the Northern Hemisphere like Imogen herself. On their home ground, Jim sees not a vagrant bird, but 'a great flock ... twisting this way and that, all at once, very precise, with all the undersides flashing white on the turn', and makes a note of his sighting to send to her (1982: 62).

Once on the front, Jim is confronted with the machinery of war. He has an instinctive fear of machinery. At fifteen, Jim had been in control of a harvester when his younger brother fell into the path of the blades. Such farming accidents are all too common, and their impact is traumatic. Jim's mother has never recovered. The memory of her looking past him to his dead brother returns as Jim loses his 'dangerous innocence' in the trenches. In France, where hedges separated ploughed fields from the battle lines, he has a 'fearful vision':

The war, or something like it with a different name, would go on growing out from here till the whole earth was involved; the immense and murderous machine that was in operation up ahead would require more and more men to work it, more and more blood to keep it running; it was no longer in control. The cattletrucks would keep on right across the century, and when there were no more young men to fill them they would be filled with the old, and with women and children. They had fallen, he and his contemporaries, into a dark pocket of time from which there was no escape. (1982: 102-3)

In contrast to Jim, Ashley embraces all that is new: the automobile, the biplane and modern music. His education in Cambridge and Germany has produced an aesthete. He plays the piano and knows Wagner well: he 'could whistle all the Leitmotifs from The Ring' (1982: 9). Though Wagner's concept of Gesamtkunstwerk (the 'total work of art') has been associated with fascism, in a recent study of the composer's relationship to modernism, Juliet Koss (2010) recovers the origins of Wagner's ideas in the 1848 revolution. Her study re-describes his aesthetics and 
politics as Utopian and democratic. Ashley Crowther's ideas can be seen in this light as well. He takes up his inheritance - a vast landholding - with a different intention from that of his forebears. They had revered tradition, even as it was plainly non-adaptive. Ashley looks to the future, and sees that the old hierarchies cannot hold. More importantly, he understands that 'all this water, all these boughs and leaves and little clumps of tussocky grass that were such good nesting places and feeding grounds belonged inviolably to the birds' (Malouf 1982: 7). The rights of ownership granted him by the Crown could not overturn their rights. And he sees that Jim, by virtue of his knowledge of the swamp and the creatures that inhabit it, also has 'an ancient and deep' claim to the land that goes beyond 'mere convention or the law' (1982: 7). By bringing Jim into his project, Ashley will legitimise his inheritance.

The bird story of the first part of the novella establishes a set of relationships among Ashley, Imogen and Jim that enable Malouf to explore ideas of tradition and modernity, the natural world and the mechanised world. This story has echoes of E.M. Forster's novel, Howards End (1910). Both are centred on the question of inheritance, and on the opposition of the values attaching to the natural world and to industrialisation. Both narratives represent a world of culture and civilisation that centres on music and conversation. Ashley brings European culture to Queensland country life just as the Schlegel sisters, especially Margaret, counteract the philistinism of the new capitalist class through their interest in music and art. The sisters and their women friends meet in a discussion club to debate how best to achieve social reform and a redistribution of wealth. Ashley has a robust vision of democratic relationships, and the means to put his ideas into action. Both novels downplay sexual relationships, and make oblique references to homoeroticism. Helen's concealment of the scandal of her pregnancy and Jim's furtive experience with the young prostitute who picks him up in a Brisbane pub highlight this absence of passion. At the end of Fly Away Peter, Miss Harcourt orchestrates the shift from past to future just as Ruth Wilcox, by leaving her country house to Margaret, reorients tradition and the past to a new more democratic future. Helen's child, conceived with the unemployed clerk Leonard Bast, will inherit Howards End. Like Malouf, Forster is interested in how the land is inhabited, and legal contracts that establish ownership of property prove to be less binding than spiritual attachments to place. Though Forster's novel is a protest against industrial capitalism, he could not foresee the war that brings an end to Malouf's idyll.

Ashley Crowther is no Wilcox. They have no regard for the past. Ashley represents the new order of things, but the past haunts him. Concealed in the wheat fields are the graves of his forebears and of siblings who died in childhood. These 'Monuments' form his 'ancestral city' (Malouf 1982: 12). As he gives new life to the house, he shares his good fortune with friends. They come to his weekend house parties, 'young fellows, and also ladies, who arrived in automobiles wearing caps or with their heads swathed in voile against the dust of country roads, to ride, to eat big meals in the lamplit house and to dance to gramophone music on the verandah' (1982: 4).

The film critic A.O. Scott has observed that 'the itineraries of modernism pass through the old - the archaic, the ancient, the atavistic - en route to the new' (2016: 28). The migrations of birds and people - Ashley's return and Miss Harcourt's arrival - trace this arc. Describing the way modernist artists used motifs of 
the exotic, the strange, and the primitive to 'shake painting, poetry and music out of their inherited patterns and complacent assumptions', Scott points to 'a feeling of belatedness that shadows the experience of modernity' (2016: 28). This feeling shadows Ashley as he returns from Europe. It manifests itself when Jim takes the house party on a tour of the sanctuary:

What he could not know was to how great a degree these trips into the swamp, in something very like a punt, were for Ashley recreations of long, still afternoons on the Cam, but translated here not only to another hemisphere, but back, far back, into some pre-classical, pre-historic, primeval and haunted world (it was this that accounted for his mood of suspended wonder) in which the birds Jim pointed out, and might almost have been calling up as he named them in a whisper out of the mists of creation, were extravagantly disguised spirits of another order of existence, and the trip itself - despite the picnic hamper and the champagne bottles laid in ice, and the girls, one of whom was the girl he was about to marry - a water journey in another, deeper sense; which is why he occasionally shivered, and might, looking back, have seen Jim, where he leaned on the pole, straining, a slight crease in his brow and his teeth biting into his lower lip, as the ordinary embodiment of a figure already glimpsed in childhood and given a name in mythology, only now made real. (Malouf 1982: 30-1)

Damien Barlow (2012: 27) comments on Malouf's use of the modernist trope of the primitive in this scene. In this 'momentous sentence', he argues, Ashley's 'numinous gaze ... transforms Jim, with his sexually suggestive pole, into a primitive object of same-sex desire'. 'Ironically,' Barlow concludes, 'we get representations of homoerotic pre-verbalism through a profusion of words, ideas, figures of speech and classical allusions' (2012: 28). However, I see this 'moment of being' differently and more simply as prefiguring the fate that awaits them on the front, when the roles are reversed and Ashley conducts Jim into the realm of death. 'Preverbal homoeroticism', I suggest, is to be found elsewhere in the novella.

Ashley marries and has a son before he goes to war. As he leads his men to the front, he is confronted by waves of casualties crowding the roads and realises that 'a new set of conditions' is emerging: war is an industry. He is visited by a grim foreboding that afterwards, 'what had been learned on the battlefield would travel back, and industry from now on, maybe all life, would be organised like war' (Malouf 1982: 112). This is the same horrific vision that strikes Jim. In France, the two men meet only twice. The final time, they enjoy an impromptu concert, performed by a motley group of soldiers. When each man is wounded in separate actions, they are taken to the same field hospital. In his delirium, Jim sees his friend bending over him, and remembers their meetings behind the lines. In his last moments, Jim hears both the song of the nightingale and the voice of a boy soldier who sang Mendelssohn's prayer at that last concert: 'in the wilderness build me a nest, and remain there forever at rest'. Ashley accompanies him as he crosses over into death, then disappears. His mate Clancy Parkett waits on the other side.

In death, Jim digs in to the 'warm, damp, delightfully crumbly' earth (1982: 126) with Clancy and the host of others, in a field 'so wide ... that you could see the curve of the earth' (1982: 127). The grave returns him to the place where he feels at home: 
He moved always on these two levels, through these two worlds: the flat world of individual grassblades, seen so close up that they blurred, where the groundfeeders darted about striking at worms, and the long view in which all this part of the country was laid out like a relief-map in the Shire Office - surf, beach, swampland, wet paddocks, dry, forested hill-slopes, jagged blue peaks. (1982: 2)

Jim represents the volunteers who enlisted in the AIF and the nation that lost its innocence on the battlefields of the Great War. The scale of Australian losses was unimaginable. As the narrative unfolds, he loses his innocence and comes to a greater understanding of himself. Malouf's 'soldier's tale' explores the depths of Jim's psychology. He remains a loner; and knows the limits of his capacity for empathy. He is drawn to Clancy, who is 'always in trouble', because he too holds back something of himself. But the crux of his experience is that he confronts his dark side. His encounters with Wizzer Green demonstrate how precarious rationality is and how swiftly restraint dissolves. On their first meeting, Wizzer picks a fight, eliciting a 'black anger' that surprises Jim. He cannot suppress his rage, but on this occasion Clancy intervenes, taking the blow intended for Jim. Thereafter, Jim avoids Wizzer, not from cowardice but because (like Conrad's Marlow) he 'wishes not to be confronted by some depth in himself, and in the other man, that frightened him and which he did not understand' (1982: 64). Another more terrifying meeting with his nemesis awaits him.

In the interval, Jim's friendship with the larrikin Clancy develops. Together, to the cheers of the other men, they had run alongside the train taking them to the front, to get hot water for their billy from the engine driver. This is a moment of pure exhilaration, a display of the youthful strength that will soon be sorely tested. On the night before they are due to join the fighting, Clancy talks Jim into cutting curfew to go to an estaminet, where the local women serve drinks and food: omelettes and pommes frites. Jim drinks vin blanc with syrup, while Clancy favours stronger stuff. Jim blushes as his friend chaffs him about his craving for sweetness - 'What is this? A kiddies' birthday do?' - but feels 'a great affection' for him (1982: 74).

After an eleven-day stint in waterlogged trenches, their company is rotated out. This respite promises a rare pleasure: a hot cup of tea, with bread and jam. Clancy has gone with the billy to get water; Jim is anticipating the first mouthful of the bread:

Jim sat astride a blasted trunk and was buttering slabs of bread, dreamily spreading them thick with golden-green melon and lemon jam. His favourite. He was waiting for Clancy to come up with water, and had just glanced up and seen Clancy, with the billy in one hand and a couple of mugs hooked from the other, dancing along in his bow-legged way about ten yards off. Jim dipped his knife in the tin and dreamily spread jam, enjoying the way it went over the butter, almost transparent, and the promise of thick, golden-green sweetness.

Suddenly the breath was knocked out of him. (1982: 82)

In this moment, Jim, whose perceptions have previously been acutely visual and aural, is intent on oral satisfaction. He is totally unaware of his surroundings. Dipping his knife into the sweet sticky mass that smells of home, he defers the pleasure of holding the jam in his mouth, waiting to share the sensation with his mate. But Clancy's dancing figure disappears. Finding himself suddenly covered in 
blood and gore, Jim slowly realises that his own body is intact. The sticky mass is Clancy, who has been blown to smithereens.

The loss of Clancy, and the fate of the 'orfing' Eric, who survives the blast but loses his legs, hardens Jim. One night, he finds himself in a crater in no man's land as the air is 'tormented' by artillery fire. As he gathers his physical and mental strength to crawl out, his leg is seized by an unknown assailant who brings him to the ground: 'They were locked fiercely, brutishly together, grunting strange words, trying to stagger upright enough to gain advantage, to get some force into their blows' (1982: 90). It is Wizzer, cringing in fear. Jim learns from this episode that there are 'so many ways of being afraid', some of them shameful and disabling. He does not want to be 'sullied' by Wizzer's cowardice; he wants to 'wipe all this clean', to use his fear to propel them both through the hissing of grenades and gunfire to safety:

So he wasn't lost after all. He had found the company, and might have considered his time out of all of this a dream, a fear of what he might do rather than of what he had done, if it weren't for Wizzer. Wizzer's face, and Wizzer's grip on him when they had wrestled together in the mud, were too real, and too humbling in his memory, to be dismissed. (1982: 93)

Wizzer is a manifestation of Jim's father, who goaded him to enlist with taunts about white feathers. Just as he fears being sullied by Wizzer, Jim had repulsed his father, not wanting to be 'infected' by his baleful view of the world. The older man is not just a violent drunk; at heart he possesses a 'kind of savagery' that could 'blast the world' to smithereens (1982: 6). He wants his son to sign up not because he is too old to fight himself, but so that he might participate in a national form of sacrifice. Jim instinctively understands his father's motives: 'Jim was depriving him of his chance to reach out and touch a unique thing, to feel that he too had dug into the new century' (1982: 54-5).

His father had sneered at his son's friendship with Imogen Harcourt, calling her a 'hatter' (1982: 46). He speaks to her for the first time when he runs into her after receiving the news of his son's death. Imogen wants to understand his grief, but he does not invite sympathy. Instead, he glares at her, exposing the same 'deep hatred for everything he saw' (1982:131) and that his son had known so intimately. There is nothing to say about this father's loss, but Imogen's grief has a critical function in the narrative.

Imogen represents the New Woman. She had travelled to the Mt Morgan mines with her brother, and when he returned home defeated, she stayed to set up an independent household and darkroom in a cottage near the swamp. Jim first catches sight of her through his field glasses. They pick out partial images: her camera; her skirt; her hat. Finally, a surrealist image comes into view: 'The composite figure that now filled the frame was of a grey skirt, voluminous and rather bedraggled, topped by a black box wearing a sun-bonnet' (1982: 20-21). They have the same bird, a sandpiper, in their sights: 'For some time, without either of them being aware of it, they had, in all this landscape, and among all its creatures, been fixing their attention from different sides on the same spot and on the same small whitebreasted body' (1982: 21). The intersection of their gazes is the intersection of Jim's empirical observation and Imogen's aesthetic frame. 
When he tells her that he is going to war, she allows herself a flash of anger. Her opposition to war is unspoken but unmistakeable. Nevertheless, she goes to the siding to see him off, and his last sight of home is of her square figure with the dirt from the locomotive swirling around her. On hearing of his death, Imogen is immobilised by sorrow. Yet she feels that she is not entitled to grieve. She holds her feelings inside until she goes to the dunes, to watch the waves. Their rhythm soothes her, and offers release:

Her mind gathered and held it, on a breath, before the pull of the earth drew it apart and sent it rushing down with such energy into the flux of things. What had torn at her breast in the fact of Jim's death had been the waste of it, all those days that had been gathered towards nothing but his senseless and brutal extinction. Her pain lay in the acute vision she had had of his sitting as she had seen him on that first day, all his intense being concentrated on the picture she had taken of the sandpiper, holding it tight in his hand, but holding it also in his eye, in his mind, absorbed in the uniqueness of the small creature as the camera had caught it in just that moment, with its head cocked and its fierce alert eye, and in entering that one moment of the bird's life - the bird was gone, they might never see it again - bringing up to the moment, in her vision of him, his own being that was just then so very like the birds, alert, unique, utterly present. (1982: 131-2)

Imogen's grief refocuses the narrative from the carnage of war to the sense of loss at home. It parallels the shift in epic from heroic action to domestic lament. Her mourning partakes of the form of classical lament that is a constitutive element of the epic (Murnaghan 1999), but that also functions as a counterpoint to epic values — in effect an 'anti-epic' (Derderian 2001). Typically, the lament also introduces the voices of women, previously marginal to the narrative of heroic action. Christine Perkell (2008: 96) has shown how the laments that conclude Book 24 of Homer's Iliad, spoken by Andromache, Hecuba and Helen, go beyond the expression of grief to 'engage the fundamental assumptions of heroic ideology'. Imogen's silent opposition to the war is now endorsed by the acknowledgement of senseless loss of life in this war.

Although the last chapter of Fly Away Peter focuses on Imogen, it also introduces Ashley Crowther's wife by name for the first time: Julia Crowther furnishes details of Jim's fate and Ashley's survival for both Imogen and the reader. In classical lament, the public occasion of mourning confers a moral authority upon the mourner and evokes a depth of feeling that authorises the scrutiny of orthodox values. Imogen feels a grief that wracks her body, yet also questions the legitimacy of her claim on his loss. She is not family; she is a migrant, but her reflection on what Jim was in life fulfils one of the key purposes of lament, providing a testimony to the character of the lost soldier. Lament thus looks in two directions: to the past and the life of the person mourned; and then to the future and the promise that loss will be redeemed. Gathering her equipment to leave the beach, the trail of her tears turning cold on her cheeks, Imogen sees 'something amazing': a surfer catching a wave, balancing on his board, moving towards her. She watches, fascinated, as the performance is repeated. As she leaves, she turns to look again:

It was new. So many things were new. Everything changed. The past would not hold and could not be held. One day soon, she might make a photograph of this 
new thing. To catch its moment, its brilliant balance up there, of movement and stillness - that would be something.

This eager turning, for a moment, to the future, surprised and hurt her. (1982: 133-4)

Jim and his mates were fishermen, whose memories of 'the bay' created bonds of friendship. But they might also have been surfers, had they lived. The first surf lifesaving club in Queensland was established at Coolangatta in 1909, and by the end of the Great War surfing culture was well established around the country. The surfer that Imogen sees embodies a new Australian masculinity, a figure who embraces the boundlessness and freedom of the ocean and who redeems the sacrifice of the civilian soldiers of the AIF. He dances on his board as it rises to the crest of the wave, recalling Clancy's lightness of being and the swooping of the birds in their element, the air. The water is the surfer's element, as the swamp had been Jim's. Imogen's photographic eye registers the brilliance of the light on water, the speed of movement of wave, body and board. She has found a new subject, and Malouf's narrative reaffirms the value of the natural world over the wasteland that industrial war will make of the twentieth century.

\section{References}

Barlow Damien 2012. "Did he want to mix and mate with this man?": Mateship, modernism and homoerotic primitivism', Australian Literary Studies 27(1): 18-32.

Barthes Roland 1982 (1980). Camera lucida: Reflections on photography, trans. Richard Howard. London: Jonathan Cape.

Batchen Geoffrey 2009. Photography degree zero: Reflections on Roland Barthes's Camera lucida. Cambridge, MA: MIT Press.

Conrad Joseph 1988 [1899]. Heart of Darkness, ed. Robert Kimbrough. New York: W.W. Norton.

Denti Joseph R. 2013. 'Conducting approaches and recommendations for the performance of Igor Stravinsky's L'Histoire du Soldat'. Unpublished PhD thesis, George Mason University.

Derderian Katherine 2001. Leaving words to remember: Greek mourning and the advent of literacy. Leiden: Brill.

Dillon Brian 2011. 'Rereading: Camera lucida by Roland Barthes', Guardian, 26 March, https://www.theguardian.com/books/2011/mar/26/roland-barthes-camera-lucidarereading.

Forster E.M. 1970 [1910]. Howards End. Harmondsworth: Penguin.

Gyger Elliott 2015. 'Insight: Fly Away Peter'. Australian Music Centre, http://www.australianmusiccentre.com.au/article/insight-fly-away-peter.

Koss Juliet 2010. Modernism after Wagner. Minneapolis, MN: University of Minnesota Press.

Malouf David 1980. First things last: Poems. Brisbane: University of Queensland Press.

— 1982. Fly Away Peter. Ringwood: Penguin.

2004. 'The one day', in Peter Craven (ed.), The Best Australian Essays 2003. Melbourne: Black Inc., pp. 95-107. 
2015. 'Melbourne Festival 2015: The story behind David Malouf's Fly Away Peter', Sydney Morning Herald, 11 September, http://www.smh.com.au/ action/printArticle? $\mathrm{id}=97794376$.

Murnaghan Sheila 1999. 'The poetics of loss in Greek epic', in M. Beissinger, J. Tylus and S. Wofford (eds), Epic traditions in the contemporary world: The poetics of community. Berkeley, CA: University of California Press, pp. 203-20.

Perkell Christine 2008. 'Reading the laments of Iliad 24', in Ann Suter (ed.), Lament: Studies in the ancient Mediterranean and beyond. New York: Oxford University Press, pp. 93-117.

Scott A.O. 2016. Better living through criticism: How to think about art, pleasure, beauty and truth. London: Jonathan Cape.

Seymour Alan 1958. The One Day of the Year. Sydney: Angus \& Robertson. 